Dicle Üniversitesi Veteriner Fakültesi Dergisi
https://dergipark.org.tr/tr/pub/duvetfd
Araştırma Makalesi/Research Article
Dicle Üniv Vet Fak Derg 2021;14(2):142-144
DOI: 10.47027/duvetfd.1014976

\title{
Üst Solunum Sistemi Problemli Kedilerde Feline Herpesvirus 1 Enfeksiyonun PCR Yöntemi ile Araştırılması
}

\author{
Aynur ŞiMŞEK ${ }^{1, a, \bowtie}$, Nazan BAKSi', b \\ ${ }^{1}$ Dicle Üniversitesi Veteriner Fakültesi İç Hastalıkları Anabilim Dalı, Diyarbakır, TÜRKiYE \\ 2Dicle Üniversitesi Veteriner Fakültesi, Laboratuvar Hayvanları Anabilim Dalı, Diyarbakır, TÜRKIYE
}

aORCID: 0000-0002-2006-6344; bORCID: 0000-0002-2758-913X

\begin{tabular}{ccc}
\hline Geliş Tarihi/Received & Kabul Tarihi/Accepted & Yayın Tarihi/Published \\
26.10 .2021 & 30.11 .2021 & 31.12 .2021 \\
\hline
\end{tabular}

Öz

Bu çalışmada, kedilerin üst solunum yolu enfeksiyonunda Feline herpesvirus 1 (FHV-1)'in rolünün belirlenmesi amaçlandı. Çalışma kapsamında 45 hasta kedinin klinik muayaneleri yapılarak FHV-1 enfeksiyonu yönünden değerlendirildi. FHV-1 enfeksiyonunun klinik bulgularını (hapşırma, gözyaşı ve burun akıntısı, salivasyon) gösterip aşı ve herhangi bir tedavi uygulanmamış 20 kedi çalışmaya dahil edildi. Kedilerden alınan orofarengeal ve konjunktival swap örneklerinde polymerase chain reaction (PCR) yöntemi ile FHV-1 varlığı araştırıldı. PCR analizlerinde kedilerin 13'ünün (\%65) FHV-1 yönünden pozitif olduğu tespit edildi. Sonuç olarak, Diyarbakır bölgesindeki kedilerin üst solunum yolu enfeksiyonunda FHV-1'in önemli rol aldığı ortaya konuldu.

Anahtar Kelimeler: Feline herpesvirus 1, Kedi, PCR, üst solunum yolu enfeksiyonu

Investigation of Feline Herpesvirus 1 Infection in Cats with Upper Respiratory System Problems by PCR

\section{Abstract}

In this study, it was aimed to determine the role of Feline herpesvirus 1 (FHV-1) in the upper respiratory tract infection of cats. In the study, clinical examinations of 45 sick cats were performed and evaluated for FHV-1 infection. Twenty cats, which showed clinical signs of FHV-1 infection (sneezing, tears and nasal discharge, salivation) and were not vaccinated and treated, were included in the study. The presence of FHV-1 was investigated by polymerase chain reaction (PCR) method in oropharyngeal and conjunctival swap samples. In PCR analysis, 13 (65\%) of the cats were found to be positive for FHV-1. As a result, it was revealed that FHV-1 plays an important role in the upper respiratory tract infection of cats in the Diyarbakir region.

Key Words: Feline herpesvirus 1, Feline, PCR, upper respiratory tract infection

\section{GiRiş}

Üst solunum yolları enfeksiyonları (ÜSYE) özellikle aşırı kalabalık veya stresli ortamlarda barındırılan yavru kedilerde önemli morbidite ve mortalite nedenidir $(1,2)$. Feline herpesvirus 1 (FHV-1), Feline calicivirus, Feline reovirus, Chamydophila felis, Mycoplasma felis, Bordetella bronchiseptica, Staphylococcus aureus, b-hemolytic streptococci ve Salmonella typhimurium kedilerde ÜSYE'nin etiyolojisinde rol alan önemli etkenlerdendir (3).

Bu etkenlerden FHV-1 Herpesviridae familyasının alt familyası olan Alphaherpesvirinae ailesinin Varicellovirus genusunda çift sarmallı DNA içeren ve glikoprotein-lipid zarfa sahip bir virüsdür. Bu nedenle dış ortama ve genel dezenfektanlara duyarlıdır. Nemli ortamda 18 saate kadar canlı kalabilen virüsün kuru ortamda yaşama süresi daha kısadır $(4,5)$. Bu virüsün sadece bir serotipi vardır ve diğer alfaherpesvirüsler gibi FHV-1 de sinir ganglionlarında latent olarak kalır (6). Stres, immunsupresyon, doğum veya transport sonucu virusun reaktive olmasıyla tekrar hastalık belirtileri ortaya çıkar. Virus enfekte kedilerin nazal, oral, ve konjunktival akıntıları ile saçılır ve direkt temas ile bulaşır $(2,6)$.

FHV-1 enfeksiyonuna her yaş, ırk ve cinsiyetteki kediler duyarlı olmakla birlikte genellikle altı aya kadar olan genç hayvanlarda hastalık daha şiddetli seyretmektedir. Hastalık depresyon, ateş, iştahsızlık, hapşırma, gözyaşı ve burun akıntısı ile karakterizedir. $(6,7)$. FHV-1 konjunktivitisin en yaygın nedeni olup aynı zamanda korneal ülser, stromal keratit, korneal ayrılma ve keratokonjunktivitis siccaya da neden olabilmektedir $(4,8)$.

Kedilerde şiddetli solunum ve konjunktival hastalık bulgularının yanı sıra belirgin hapşırma FHV-1 enfeksiyonunu düşündürmekle birlikte (9) serolojik, virolojik ve moleküler teknikler ile tanı konulmaktadır. Moleküler bir teknik olan polymerase chain reaction (PCR) yüksek duyarlılığı nedeniyle öncelikle tercih edilmektedir (10).

Toplu olarak barındırılan ÜSYE'li kedilerdeki prevalans verileri hastalığın yönetim, tedavi ve yayılmasının önlenmesine büyük katkı sağlamaktadır $(10,11)$. Yapılan literatür 
taramalarında Diyarbakır bölgesindeki ÜSYE'li kedilerde FHV-1'in rolünün araştırıldığı herhangi bir çalışmaya rastlanılmamıştır. Bu nedenle bu çalışma ile bölgemizde üst solunum sistemi problemi olan kedilerde FHV-1 enfeksiyonunun varlığının PCR yöntemi ile ortaya konulması ve klinik semptom gösteren kedilerde hastalığın insidansının belirlenmesi amaçlanmıştır.

\section{MATERYAL VE METOT}

Çalışma kapsamında ÜSYE bulguları olan farklı ırk, yaş ve cinsiyetteki 45 hasta kedinin klinik muayeneleri yapılarak FHV1 enfeksiyonu yönünden değerlendirildi. Anamnezlerinde FHV-1'e karşı aşı veya tedavi uygulandığı bilgisi alınan 25 kedi çalışma kapsamından çıkarıldı. FHV-1 enfeksiyonunun klinik bulgularını (hapşırma, gözyaşı ve burun akıntısı, salivasyon) gösterip aşı ve herhangi bir tedavi uygulanmamış 20 kedi çaIışmaya dahil edildi.

Hastalardan 20 orofarengeal 20 konjunktival olmak üzere toplam 40 swap örneği alındı. Alınan örnekler, EMEM (Eagle's Minimum Essential Medium) solüsyonu içeren tüplere konularak soğuk zincirde Dicle Üniversitesi Veteriner Fakültesi Genetik Anabilim Dalı Laboratuvarına ulaştırıldı.

\section{DNA Ekstraksiyonu}

Swap örneklerinden FHV-1 ekstraksiyonu için ticari DNA ekstraksiyon kiti (BioBasic EZ-10 Spin Column Viral DNA Miniprep Kit CAT.\#: VT81812) kullanıldı.

\section{Polymerase Chain Reaction (PCR)}

PCR yöntemi ile FHV-1 tespiti, FHV-1'in timidin kinazı kodlayan ve 287 bç'lik bir DNA fragmanını amplifiye eden 5'GACGTGGTGAATTATCAGC-3' ve 5'-CAACTAGATTTCCACCAGGA-3' primerleri kullanılarak yapıldı (12). PCR ISı döngüleri $95^{\circ} \mathrm{C}^{\prime}$ de 5 dakika ön denatürasyon, 35 döngü $90^{\circ} \mathrm{C}^{\prime}$ de 1 dakika, $56^{\circ} \mathrm{C}^{\prime}$ de 1 dakika ve $72^{\circ} \mathrm{C}^{\prime}$ de 1 dakika ve $72^{\circ} \mathrm{C}^{\prime}$ de 4 dakika son uzama basamağı şeklinde uygulandı.

Elde edilen PCR ürünleri, etidyum bromür içeren \%1.5 agaroz jel içinde elektroforeze tabi tutulduktan sonra UV ışığı altında görüntülendi. Pozitif kontrol olarak ticari aşı (Felocell ${ }^{\circledR}$-CVR, Zoetis Animal Health, USA) referans alınmış olup bu doğrultuda yapılan PCR sonucunda 287 bç'lik bir DNA bandı elde edilen örnekler pozitif kabul edildi (Şekil 1).

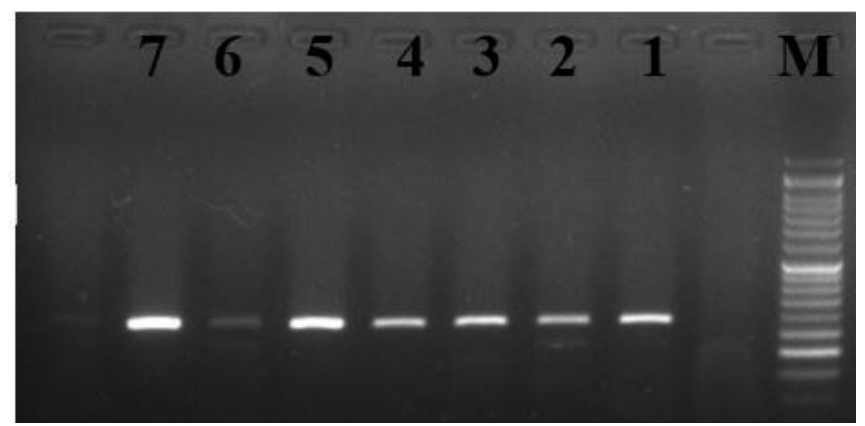

Şekil 1. FeHV-1 amplifikasyon ürünlerinin \%1.5 agaroz jel içindeki görüntüsü. M: 50-bç'lik DNA standardı, 1-6: Pozitif orofarengeal ve konjunktival swab örnekleri, 7: Aşı (pozitif kontrol).

\section{BULGULAR}

Araştırmanın materyalini oluşturan hastaların klinik muayenelerinde gözyaşı, burun akıntısı, oral lezyonlar ve salivasyon tespit edildi (Şekil 2). Mukopurulent burun akıntısı olan kedilerin çoğunda akıntının kuruyarak burun deliklerini kapatmasına bağlı olarak solunum güçlüğü görüldü.
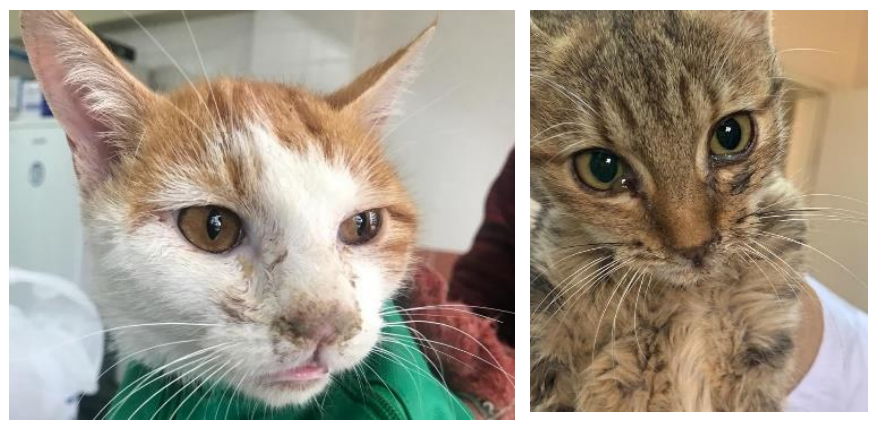

Şekil 2. Gözyaşı ve burun akıntısı

PCR analizlerinde ÜSYE semptomlu kedilerin 13'ünün FHV-1 yönünden pozitif olduğu tespit edildi. Hasta kedilerden alınan 20 orofarengeal, 20 konjunktival olmak üzere toplam 40 swap örneğinin 17 'sinin FHV-1 pozitif olduğu tespit edildi (Tablo 1).

Tablo 1. ÜSYE'li kedilerin orofarengeal ve konjunktival swap örneklerinin PCR bulguları

\begin{tabular}{lc}
\hline Örnek & FHV-1 pozitif örnek sayısı \\
\hline Orofarengeal & 9 \\
Konjunktival & 8 \\
Orofarengeal + Konjunktival & 4
\end{tabular}

\section{TARTIŞMA VE SONUÇ}

Kedilerde solunum yolu hastalıklarının önemi ve özellikle toplu olarak barındırıldıklarında artan prevalansı nedeniyle, etken mikroorganizmaların araştırılması gerekli olduğu bildirilmektedir (13). Bu çalışma Diyarbakır bölgesinde ÜSYE'li kedilerde FHV-1'in araştırıldığı ilk çalışmadır.

Kedilerin \%90'ından fazlasının FHV-1 seropozitif olduğu, büyük çoğunluğunun yaşamları boyunca latent olarak enfekte kaldığı ve latent olarak enfekte olmuş kedilerin ise yaklaşık \%45'inin yaşamı boyunca virüs saçtığı bildirilmekte$\operatorname{dir}(14)$.

ÜSYE'li kedilerde FHV-1'in prevalansını İspanya'da Fernandez ve ark. (15) \%28.3, İran'da Najafi ve ark. (13) \%43, Avustralya'da Sykes ve ark. (3) \%17.3, Brezilya'da Henzel ve ark. (6) \%13, Japonya'da Cai ve ark. (16) \%16.7, dokuz Avrupa ülkesinde (Avusturya, Fransa, Almanya, İtalya, Hollanda, İspanya, İsveç, İsviçre ve Birleşik Krallık) Helps ve ark. (17) \%16 olarak bildirmişlerdir.

Ülkemizde bu konuda yapılan çalışmalar sınırlı olup Küçük ve ark. (10) FHV-1'in prevalansını sağlıklı görünüşlü kedilerde \%16.7 solunum sistemi problemli kedilerde ise \%47.6 olarak bildirmişlerdir. Bilge Dağalp ve Akça (18) FHV-1 pozitiflik oranlarını sağlıklı görünüşlü kedilerde \%7.3, ÜSYE bulguları olan kedilerde ise \%18.1 olarak bildirmişlerdir. Bilge Dağalp ve ark. (7) solunum sistemi problemli kedilerde \%45.71, Karapınar ve ark. (19) konjunktivitisli Van kedilerinde \% 45, Bayraktar ve Yılmaz (20) hasta ve sağlıklı kedileri 
değerlendirdikleri araştırmalarında \%43.3 ve Abaylı ve ark. (21) ise \%12.9 olarak bildirmişlerdir.

Mevcut araştırmada ÜSYE'li kedilerin \%65'inde (13 / 20) FHV-1 tespit edilmiş olup bu oranın ülkemizde yapılan araştırmalarda $(7,10,18,19)$ bildirilen oranlardan oldukça yüksek olduğu görülmüştür. Ayrıca swap örneklerinin sadece hasta kedilerden alındığı, sağlıklı görünümlü kedilerde de virus saçılımının olduğu ve gençlerde hastalığın daha şiddetli seyrettiği göz önünde bulundurulduğunda FHV-1 enfeksiyonunun Diyarbakır bölgesindeki kediler için önemli bir problem olduğu belirlendi.

Sonuç olarak; Diyarbakır bölgesinde FHV-1 enfeksiyonunun yaygın olarak görüldüğü tespit edildi. Hastalığın bulaşma şekli dikkate alındığında hayvanların toplu olarak barındırılıkları yerlerde temizlik ve dezenfeksiyon işlemlerine dikkat edilmesi, kedilerin kalabalık barındırılmalarının önlenmesi ve aşılamaların düzenli olarak uygulanması ile hastalığın insidansının azaltılabileceği kanaatine varıldı.

\section{TEŞEKKÜR}

PCR analizlerindeki katkılarından dolayı Doç. Dr. İbrahim Halil YILDIRIM’a, teşekkür ederiz.

\section{KAYNAKLAR}

1. Sykes JE. (2014). Pediatric Feline Upper Respiratory Disease. Vet Clin Small Anim. 44: 331-342.

2. Albay MK. (2018). Kedi Gribi: Kedilerin Üst Solunum Sistemi Hastalık Kompleksi Turkiye Klinikleri J Vet Sci Intern Med-Special Topics. 4(1): 29-34.

3. Sykes JE, Allen JL, Studdert VP, Browning GF. (2001). Detection of Feline Calicivirus, Feline Herpesvirus 1 and Chlamydia Psittaci Mucosal Swabs by Multiplex RT-PCR/PCR. Vet Microbiol. 81: 95108.

4. Küçük A, Yıldırım Y. (2018). Felide Herpes Virus-1 Enfeksiyonu. Etlik Vet Mikrobiyol Derg. 29(1): 76-81.

5. Gaskel R, Dawson S, Radford A, Thiry E. (2007). Feline herpesvirus. Vet Res. 38: 337-354.

6. Henzel A, Brum MCS, Lautert C, Martins M, Lovato LT, Weiblen R. (2012). Isolation and Identification of Feline Calicivirus and Feline Herpesvirus in Southern Brazil. Braz J Microbiol. 43(2): 560-568.

7. Bilge Dağalp S, Doğan F, Farzani TA, Babaoğlu AR, Acar Kırmızı $\mathrm{G}$, Çabalar M. (2019). Solunum sistemi problemli kedilerde $\mathrm{Fe}$ line Herpesvirus 1 (FHV-1) ve Feline Calicivirus varlığının moleküler olarak araştırılması. Eurasian J Vet Sci. 35(3): 131-138.

8. Kang BT, Park HM. (2008). Prevalence of Feline Herpesvirus 1, Feline Calicivirus and Chlamydophila Felis in Clinically Normal Cats at a Korean Animal Shelter. Journal of Veterinary Science. 9(2): 207-209.

9. Gaskell RM, Radford A, Dawson S. (2012). Feline Respiratory Disease. In: Infectious Disease of Dog and Cats. Green CE (ed.). 4th ed. pp. 151-162. Saunders Elsevier, Missouri, USA.

10. Küçük A, Sağ N, Çakır C, Acar G, Yıldırım Y, Ataseven VS. (2017). Sağılıkı görünüşlü ve solunum sistemi problemli barınak kedilerinde Feline Herpesvirus Tip 1 (FeHV-1) Enfeksiyonu. Erciyes Üniv Vet Fak Derg. 14(1): 25-30.
11. Litster A, Wu CC, Leutenegger CM. (2015). Detection of Feline Upper Respiratory Tract Disease Pathogens Using A Commercially Available Real-Time PCR test. The Veterinary Journal. 206: 149-153.

12. Sykes JE, Browning GF, Anderson G, Studdert VP, Smith HV. (1997). Differential Sensitivity of Culture and The Polymerase Chain Reaction for Detection of Feline herpesvirus 1 in Vaccinated and Unvaccinated Cats. Arch Virol. 142: 65-74.

13. Najafi $H$, Madadgar $O$, Jamshidi $S$, Langeroudi AG, Lemraski MD. (2014). Molecular and Clinical Study on Prevalence of Feline Herpesvirus Type 1 and Calicivirus in Correlation with Feline Leukemia and Immunodeficiency Viruses. Vet Res Forum. 5(4): 255-261.

14. Maggs DJ. (2005). Update on Pathogenesis, Diagnosis, and Treatment of Feline Herpesvirus Type 1. Clin Tech Small Anim Pract. 20: 94-101.

15. Fernandez M, Manzanilla EG, Lloret A, León M, Thibault JC. (2017). Prevalence of Feline Herpesvirus-1, Feline Calicivirus, Chlamydophila Felis and Mycoplasma Felis DNA and Associated Risk Factors in Cats in Spain with Upper Respiratory Tract Disease, Conjunctivitis and/or Gingivostomatitis. J Feline Med Surg. 19(4): 461-469.

16. Cai Y, Fukushi H, Koyasu S, Kuroda E, Yamaguchi T, Hirai K. (2002). An Etiological Investigation of Domestic Cats with Conjunctivitis and Upper Respiratory Tract Disease in Japan. J Vet Med Sci. 64(3): 215-219.

17. Helps CR, Lait P, Damhuis A, et al. (2005). Factors Associated with Upper Respiratory Tract Disease Caused by Feline herpesvirus, Feline calicivirus, Chlamydophila felis and Bordotella bronchiseptica in Cats: Experience from 218 European Catteries. Veterinary Record.156: 669-673.

18. Bilge Dağalp S, Akça Y. (2004). Detection of Feline Herpesvirus1 From Domestic Cats with or without Respiratory Symptoms. Indian Vet J. 81(1): 11-15.

19. Karapınar Z, Dinçer E, Ataseven VS, Karaca M. (2014). Felid Herpesvirus-1 infection in Van Cats with Conjunctivitis. YYU Vet Fak Derg. 25(1): 15-17.

20. Bayraktar E, Yılmaz H. (2020). Molecular Detection and Clinical Aspects of Feline Herpesvirus-1, Feline Immunodeficiency Virus and Feline Leukemia Virus in Cats in Istanbul, Turkey. Pak Vet J. 40(2): 249-252.

21. Abayli H, Can Sahna K, Ozbek R, Aslan O, Tonbak S, Bulut H. (2021). Detection and molecular characterisation of feline viruses from swab samples. Acta Veterinaria Hungarica. 69(2): 194203.

\footnotetext{
Sorumlu Yazar:

Aynur ŞiMŞEK

Dicle Üniversitesi, Veteriner Fakültesi, İç Hastalıkları Ana-

bilim Dalı, Diyarbakır, TÜRKiYE

E-posta: simsekvet@gmail.com
} 